\title{
The Variants of Raden Kamandaka Story in Some Areas in Banyumas District
}

\author{
Fitri Nur Rakhmawati* \\ Javanese Language Education of Graduate School \\ Universitas Negeri Yogyakarta \\ Yogyakarta, Indonesia \\ fitrinr17@gmail.com
}

\author{
Suwardi Endraswara \\ Javanese Language Education of Graduate School \\ Universitas Negeri Yogyakarta \\ Yogyakarta, Indonesia \\ suwardi_endraswara@gmail.com
}

\begin{abstract}
Raden Kamandaka story is folklore that spread across severals districts in Banyumas regency which has many versions and variants. This story has various variants that evolved in accordance with region of speakers, both of oral and written tradition. This research is centered on the oral tradition of Raden Kamandaka story in some areas of Banyumas district. The method used is qualitative methods that is presented with descriptions. This research uses narrative analysis. A variant of the story is a description of what is potrayed in the narrative. The analysis of story is divided into events and existence. Events consist of actions and happenings. Existence consist of characters and setting. Based on this research, the ten variants of the story of Raden Kamandaka are obtained from ten speakers as data. The results of the ten variants of the story obtained a variant of the story which is considered as the main story or the master story; it is the story that possesses important event. The ones which are not the master story variant are considered as a supporting or complementary variant of the story. Based on the main story, the central areas of Raden Kamandaka story are discovered. Variant II, III, IV, VII, and $X$ are assumed to be the main variant. Then, variant $I$, V, VI, VIII, and IX as supporting or complementary variant of the story.
\end{abstract}

Keywords-Oral Tradition, Variants of Raden Kamandaka Stories, Narrative Analysis

\section{INTRODUCTION}

Raden Kamandaka story is one form of oral literature contained in Banyumas, Central Java. Raden Kamandaka story spreads from the Sunda in the territory of the Pajajaran Kingdom to Banyumas which cause Raden Kamandaka story has many variants. Oral literature is a literary text spoken orally. These characteristics indicate the two elements at once, value and manner (Taum, 2011). According (Taum, 2011), oral literature is a valuable literary discourse, qualifies as literature that has rules of its own aesthetic and poetic by nature and means of literature (literary or literaturnost). Oral literature in general is spoken in various regional languages of Nusantara (Taum, 2011). Oral literature is literature that includes the literary expression of citizens a culture propagated and hereditary delivered by word of mouth (Hutomo, 1991).

Oral literature is part of the oral tradition or which are usually developed in a oral culture in the form of messages, stories, or stories, or something transmitted orally from one generation to the next other (Vansina, 1985 via Taum, 2011). Message, story, or testimony is conveyed through speech or singing, in forms such as fairy tales, proverbs, ballads, or poetry. Through this way, people can pass on the history, literature, law, and insights without a writing system (Vansina, 1985 via Taum, 2011).

Oral literature is always present in variants as a result of the way of inherit or transmission which is by word of mouth or with a sample / motion, and auxiliaries reminders (mnemonic device). Many variants among others caused by (a) forgetting, (b) the interpolation process, (c) transformations. Nonetheless, core or basic forms of oral literature is relatively fixed, particularly sacred oral literary texts (Taum, 2011). Oral literature is also part of the folklore. As other folk stories, Raden Kamandaka also part of folklore. Folklore comes from two root words folk and lore (Danandjaja, 1984: 1). According to James Danandjaja (1984) folklore is part of a collective culture that spread and inherited from generation to generation, in traditionally various form, either verbally or pattern accompanied by gestures or auxiliaries reminders (mnemonic device).

Generally Indonesian people are more familiar with folklore that already recorded and often used as teaching material in schools, such as Malin Kundang (from West Sumatra), Jaka Tarub (Central Java), Lake Toba ( North Sumatra), Roro Jonggrang (Yogyakarta), Calon Arang (Bali) and a few others. While folklore thet already recorded but rarely used as teaching material in schools, or even stories people who have not been recorded, very rarely known (Rokhmansyah, 2016). In addition, because of the advancement of technology and information, the younger generation is rarely willing to listen the oral literature from their parents. They prefer to access the stories by audio or audio visual. According to Setiawanti (2014) the younger generation is more interested in finding and seeing trendy information in communication media and electronic media such as radio and television rather than finding out folklore from their own area. This causes the importance to conducting oral literary studies.

Raden Kamandaka stories is popular among the people of Banyumas. Many places located in the district of Banyumas that used as the setting in the story of Raden Kamandaka still exist and used nowaday. There is also a toponym or places named because it related to events experienced by Raden Kamandaka. Raden Kamandaka is the pseudonym Raden Banyak Catra, the eldest son of King Siliwangi as the crown prince of the Kingdom of Pajajaran. Raden Banyak Catra name itself is well known among the Sundanese people. The name of Kamandaka consist of kama mean lust or desire, to have a wife who looks like his mother Raden Kamandaka did jajah desa milangkori or wander in the Pajajaran but the desired princess was not found. Kamandaka got a hint from Ki Ajar Mirangrong to search to 
the south of Mount Agung, or Mount Gedhe, now called Mount Slamet. There, Kamandaka will meet the youngest daughter of Pasirluhur who looks like her mother (Priyadi, 2002).

This study will focus on examining the distribution of oral literature Raden Kamandaka story in Banyumas by using ten variants of the story spread across several districts. Differences and similarities found in variants Raden Kamandaka story are interesting to learn such as the similarities and differences of mentioned characters and place and the toponyms in the background story of Raden Kamandaka. Further interesting things to do in this assessment is story completion of each variant that due to several factors. One of these factors is informant closeness of kinship with the Kadipaten Pasirluhur Informant's area which is become the setting of the story causing more detail mention to the background of the place purposed to the existence of the region. Other factor is the completeness of the collective memory of the informant. So, it is known how Raden Kamandaka story spread in the district of Banyumas especially in the object of study area.

\section{RESEARCH METHODS}

Folklore has version and variant. Version is every utterance repetition of a form of folklore, while the variant is a version that has a fundamental difference with other folklore form (Danandjaja, 1984). This study use ten variants obtained from ten speakers scattered in the district Kedungbanteng, Karanglewas, North Purwokerto, East Purwokerto, and South Purwokerto. The method used is a qualitative research method. Sources of data obtained through interviews to ten speakers in 2016 from February to April. Therefore, data obtained in this study a descriptive data.

The data collection techniques on the Raden Kamandaka story are observation, interview, and documentation. The data analysis techniques include tabulation, clarification, and interpretation. Tabulation is putting the data into tables. Clarification is selecting the data based on the types of data. Then, interpretation is explaining or interpreting data from the original ones.

As other folk stories, Raden Kamandaka also part of folklore. According to the concept of folklore, folklore Raden Kamandaka classified as figure legends and legends place. Legend is a narrative description or narrative folklore regarding the events that occurred, so that the legend can also be classified as a narrative story.

Narrative is a communication between sender and receiver. Structural theory of narrative states that every narrative has two parts, the story and discourse. The story or the content is communicated by means of discourse or in other words, the story is what is depicted in the narrative. Stories such as the chain of events or events coupled with the presence or existents that include characters and background (setting) (Chatman, 1980). Chatman concept depicted in this diagrammatic form.

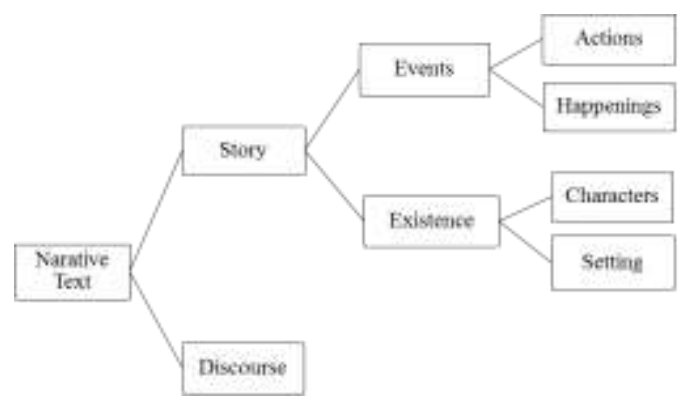

Fig 1. Diagram of narrative texts Seymour Chatman (1980: 19)

This study will focus on the story. An event consists of actions and happenings, while a form of existence consists of characters and background elements/ settings. The events are presented in a logical and hierarchical narrative. Logical nature implies that those events interwoven with other events that are causal (Chatman, 1980). Hierarchical nature of the incident showed that the one with the other events has its different levels of interest, virtues, and the functionality of the narrative structure.

\section{DISCUSSION}

Raden Kamandaka story classified according to the Chatman narrative analysis that focuses on the story. The story is divided into two: the existence and events. First step is data analyze by classifying the setting, characters, and actions. This classification places calculates the quantity setting, action figures, and characters in the story of Raden Kamandaka of each variant and the overall ten variants. Second, classify the occurred events and determine the key events that become the story generator, sourced from ten story variant.

\section{A. Story Setting Identification}

Identification is done by collecting the form of a place setting equipped by tabulated mention of the characters, action of figures, and variants. Each setting then identified by inserting any variant in accordance with the place settings, characters, and action of figures. Variants story obtained from ten speakers.

Through setting identification can determined which variants using the place settings, characters and action figures as well as any variant that does not use the setting, characters, and action figures mentioned by the story of each variant, or according to the narrative of each speaker. Differences and similarities of each variant is based on the identification of the place settings, characters, and action figures have been the story of Raden Kamandaka variation. Figures and action of figures compiled based approach to the ten variants, especially a variant has the most complete story and most have similarities with other variants, and complementary of variants. 
TABLE I. EXAMPLE OF STORY SETTING IDENTIFICATION

\begin{tabular}{|c|c|c|c|c|}
\hline No & Place & Figure & Action & Variant \\
\hline \multirow[t]{2}{*}{1} & \multirow[t]{2}{*}{$\begin{array}{l}\text { Pajajaran } \\
\text { kingdom }\end{array}$} & $\begin{array}{l}\text { 1. King } \\
\text { Siliwangi } \\
\text { 2. Raden } \\
\text { Banyak Catra } \\
\text { 3. Raden } \\
\text { Banyak } \\
\text { Ngampar } \\
\text { 4. Raden } \\
\text { Banyak Blabur } \\
\text { 5. Retna } \\
\text { Pamekas }\end{array}$ & $\begin{array}{l}\text { King Pajajaran, } \\
\text { Prabu Siliwangi } \\
\text { want to abdicate. } \\
\text { His crown } \\
\text { prince, Raden } \\
\text { Banyak Catra, is } \\
\text { expected to } \\
\text { succeed the } \\
\text { throne of the } \\
\text { King, but with } \\
\text { the condition that } \\
\text { he have married. }\end{array}$ & $\begin{array}{c}\text { I, II, III, } \\
\text { IV, V, } \\
\text { VI, VII, } \\
\text { VIII, } \\
\text { IX, X }\end{array}$ \\
\hline & & $\begin{array}{l}\text { Raden Banyak } \\
\text { Catra }\end{array}$ & $\begin{array}{l}\text { Raden Banyak } \\
\text { Catra wandered } \\
\text { to look for a wife } \\
\text { who looks like } \\
\text { her mother. }\end{array}$ & $\begin{array}{c}\text { I, II, III, } \\
\text { IV, V, } \\
\text { VI, VII, } \\
\text { VIII, } \\
\text { IX, X }\end{array}$ \\
\hline
\end{tabular}

In each setting there are character who take action or interact each other, not only one, but can be more. There was also a character in a similar setting, but do not interact with the other characters. A place setting can be used once or more than once, with the same characters or different characters. This identification may indicate any variant which uses all the place settings, and any variant that does not use the place settings that have been mentioned. A large number of variants showed similarities using the settings in each variant of the story, or in other words, show similarities story of each of these variants for setting the places mentioned by Raden Kamandaka storyline. More place settings used in a variant of the story indicates a resource provides detailed information. Setting place resulting from this identification are 51 places. If identification settings on each variant of the story just to find any used setting without repetition generate as much as 58 place settings. The settings used anywhere without regarding to the plot and action figures. Variants of the story using each setting then sum together to be a number of variants.

TABLE II. EXAMPLE OF SETTING IDENTIFICATION AND VARIANTS WITHOUT REGARDING TO FIGURES AND ACTION OF FIGURE

\begin{tabular}{|c|l|l|c|}
\hline No. & \multicolumn{1}{|c|}{ Setting } & \multicolumn{1}{|c|}{ Variants } & $\begin{array}{c}\text { Number of } \\
\text { Variant }\end{array}$ \\
\hline 1 & Pajajaran kingdom & $\begin{array}{l}\text { I, II, III, IV, V, } \\
\text { VI, VII, VIII, } \\
\text { IX, X }\end{array}$ & 10 \\
\hline 2 & $\begin{array}{l}\text { Tungkeban } \\
\text { Village, } \\
\text { Mount Tungkeban }\end{array}$ & $\begin{array}{l}\text { II, III, IV, VII, } \\
\text { X }\end{array}$ & 5 \\
\hline
\end{tabular}

Total place settings are 58 places. Place settings which have ten [10] the number of variants are four [4] Pajajaran Kingdom, Kadipaten Pasirluhur, Karanganjing hamlet, and Watu Sinom at Keniten. Place settings which have nine [9] the number of variants of one [1] setting the place Kaputren, Pancaniti. Place settings which have eight [8] the number of variants are four [4] setting where the Kadipaten Pasirluhur, Logawa River, forests, and Nusakambangan. Place settings which have seven [7] the number of variants of one [1] setting the Bobosan hamlet. Place settings which have six [6] number of variants are four [4] ie Tamansari, Kedung Petaunan, Batur Agung, and Kabunan forest. Place settings which have five [5] the number of variants are four [4] which Tungkeban Village or Tungkeban Mountain, Home of Nyai Kertisara, Pangebatan, and Kober hamlet. Place settings which have four [4] variants of two [2] ie Suruplawang Cave and Banjaran river. Place settings which have three [3] the number of variants of the ten [10] that is in the room of Dewi Ciptarasa, Kedung Branangsiyang, Karangayam, Ajogol/Pejogol, Apa river, Kebocoran Hamlet, Baturraden, Kalipapag at Jatisaba, Kandang Aur and the battlefield. Place settings which have two [2] number of variants, there are five [5] that Situsekar, Jengok River, Bodhas River, and Gerbohe. Place settings which have one [1] the number of variants exist 23 Raden Kamandaka grandparent's house, Gadhug village, Karanglewas, Beji, Karangnangka, Kali Kesur, Kutaliman, Salarendeng, Kali Putra, Melung, Depok, Windusari, Pondok Klakah, Batulaya, Baturanak, Cibun, Sunyalangu, Babakan, Karanggandhul, Jipang, Panusupan, Notog, and Buntu.

Such identification is used to process subsequent analysis. Fifty-eight place settings that have been obtained previously identified from the most commonly used until the most rarely used based on the number of variants. The most frequently used setting has ten variants, while setting where most rarely used has 1 variant. There are two category of settings, the big and small settings. Big setting has figures playing of five [5] to ten [10] variants. Small setting has figures playing of one [1] to four [4] variants or in other words a small setting only on a limited variant. This suggests that a big set used as the background of the story. Small setting shows informant is familiar with the areas adjacent both to the informant and Raden Kamandaka character, besides informant's urge to highlight his regions to be different from the other variant.

\section{B. Story Figures Identification}

Figure identification based on version and variant are used to determine existed characters in Raden Kamandaka story and also naming differences in each story variant. Each character included in any of the variants are mentioned to examine each characters utilization. Then of variants is summed to show how many variant that uses a character's name.

TABLE III. EXAMPLE OF FIGURES IDENTIFY

\begin{tabular}{|c|l|l|c|c|}
\hline No & \multicolumn{1}{|c|}{ Figures } & \multicolumn{1}{|c|}{ Information } & Variants & Tot \\
\hline 1 & $\begin{array}{l}\text { King } \\
\text { Siliwangi }\end{array}$ & $\begin{array}{l}\text { King Pajajaran, } \\
\text { father of Raden } \\
\text { Banyak Catra }\end{array}$ & $\begin{array}{l}\text { I, II, III, IV, } \\
\text { V, VI, VII, } \\
\text { VIII, IX, X }\end{array}$ & 10 \\
\hline 2 & $\begin{array}{l}\text { Raden } \\
\text { Banyak Catra }\end{array}$ & $\begin{array}{l}\text { Pajajaran king } \\
\text { crown prince }\end{array}$ & $\begin{array}{l}\text { I, II, III, IV, } \\
\text { V, VI, VII, } \\
\text { X }\end{array}$ & 8 \\
\hline 3 & $\begin{array}{l}\text { Retna } \\
\text { Pamekas }\end{array}$ & $\begin{array}{l}\text { Pajajaran king's } \\
\text { daughter from } \\
\text { his second wife }\end{array}$ & II, III, X & 3 \\
\hline
\end{tabular}

This identification resulted in 75 names of characters, including the mention of the name of a different character but refers to one character Subsequent analysis is sort the use frequency of each characters. Total figure of ten variants of the story then resulted in 61 names of characters without any differences in name character after tailored to the character's 
name reference. There are two group based on this identification, figures that appear in ten [10] to five [5] variants are included in major character, while appearance in four [4] to one [1] included in minor character Major character group are included main characters or have important role in Raden Kamandaka's variants of the story, while minor group are supporting characters or few significant role in the Raden Kamandaka's variants of the story.

\section{Action of Figures Identification}

Obtained the actions of all the characters as much as 118 actions through an approach to actions in all collected variants of the story. Actions are identified as described in TABLE IV (Sample nof Action figures identification). Each appeared action in a variant is checked [v] then summed to count how many variants that use the action of figures in the story.

Variant I has 34 action of figures, Variant II has 82 action of figures, variant III has 114 action of figures, Variant IV has 40 action of figures, variant $\mathrm{V}$ has a 59 action of figures, Varian VI has 39, Varian VII has 53, Varian VIII has 32, Varian IX has 28, and Varian X has 118 action of figures. These results indicate that the majority of action possessed by Varian $\mathrm{X}$ with a number of actions as much as 118 action then Variant III having a number of actions as much as 114 action. The number of actions that are used in a variant of the story of Raden Kamandaka shows completeness of a variant of the story. Therefore, acquired sequence variants that indicated most complete until the variant indicated incomplete. Sequence variants are starting from Varian X, variant III, Variant II, variant V, VII Varian, Varian IV, VI Varian, Varian I, Varian VIII, and a variant of the latter is Varian IX.

TABLE IV. SAMPLE OF ACTION FIGURES IDENTIFICATION

\begin{tabular}{|c|c|c|c|c|c|c|c|c|c|c|c|c|c|}
\hline No & $\begin{array}{l}\text { Action } \\
\text { figures }\end{array}$ & 1 & 2 & 3 & 4 & & & 6 & 7 & $\overline{8}$ & s & & Tot \\
\hline 1 & $\begin{array}{l}\text { King } \\
\text { Pajajaran, } \\
\text { King } \\
\text { Silihwangi } \\
\text { want to } \\
\text { abdicate. } \\
\text { Namely his } \\
\text { crown } \\
\text { prince } \\
\text { Raden } \\
\text { Banyak is } \\
\text { Catra is } \\
\text { expected to } \\
\text { succeed the } \\
\text { throne of } \\
\text { the King, } \\
\text { but with the } \\
\text { condition } \\
\text { that he was } \\
\text { married. }\end{array}$ & $\mathrm{v}$ & $\mathrm{v}$ & $\mathrm{v}$ & & & & $\mathrm{v}$ & $\mathrm{v}$ & $\mathrm{v}$ & t & & 10 \\
\hline 118 & & & & & & & & & & & & & \\
\hline & Amount & & & & & & & & & & & & \\
\hline
\end{tabular}

\section{Story Milestones}

The events can be interpreted as a transition from one state to another (Luxemburg et al, 1992 via Nurgiyantoro, 2012). Main variant is not only in terms area of informants. Variant that assumed as complete has closeness with the characters as well as close to the center of the kingdom Pasirluhur, not only judged by the setting quantity, characters, and action of figures that are used in a variant, but also can be seen from the story itself.

One story has the characters, action, and setting. The encounter or interaction of characters in a setting then has an action that drives the story becomes an important element. The interaction among characters in an action then trigger further action by the main character that means part of the movement. The movement that trigger the main character to perform the next action based on the interaction with the supporting cast is referred to as key events driving the story.

Based on the data obtained from the story of an event, action figures Raden Banyak Catra met a priest named $\mathrm{Ki}$ Ajar Mirangrong in Tungkeban or Mount Tungkeban. Ki Ajar Mirangrong told Raden Banyak Catra will find the princess in the East, which is the area Tengahan, in Pasirluhur country. The journey Raden Banyak Catra to the East or Ki Ajar Mirangrong clue is regarded as an important event because it used as a driving force for the next action of figure, the figure Raden Banyak Catra mission to find his desired wife.

An important event in this regard Raden Banyak Catra meeting with Ki Ajar Mirangrong that serve as the driving force of this story is owned by Varian II, III, IV, VII and X. Continuation story Raden Banyak Catra meeting with $\mathrm{Ki}$ Ajar Mirangrong in variants have such an important event. Further Raden Banyak Catra traveled to East indicated by mentioning many settings such as the names of the bypassed villages and interaction with other characters. Therefore, the variants that have an important event is considered as important variant or assumed as the main variant.

Variants exclude to the main variants are I, V, VI, VIII, and IX that considered as supporting or complementary variant. Variant I, V, VI, VIII, and IX are considered incomplete because it does not have the key events the meeting of Raden Banyak Catra with Ki Ajar Mirangrong. Therefore, it is likely that variants have less action of figures, setting, or mention of the figure than the main variants, Variant II, III, IV, VII and X.

There are several factors that assumed influence the occurrence of Raden Kamandaka's story variants, so that each variant of the story has a difference in the mention of the story's settings, characters or figures, action of figures, and story milestone. One of these factors is informant closeness of kinship with the Kadipaten Pasirluhur. Informant's area which is become the setting of the story causing more details mention to the background of the place purposed to the existence of the region. Another factor is the completeness of the collective memory of the informant. So, it is known how the story of Raden Kamandaka spread in the district of Banyumas especially in several subdistricts that were used as research objects. According to Sabakti (2016) the differences the development of the story in folklore shows the influence of the local culture to the narrator. That 
difference that who inflict a different versions or variants of folklore.

\section{CONCLUSIONS}

This study describes the narattive analysis of Raden Kamandaka story in Banyumas. The study was limited to the study of Raden Kamandaka story by analyzing the existence and events then narrowed to the settings, characters, and actions analysis.

Major settings considered as a background of the story. Minor setting shows familiarity of informant with the adjacent areas of Raden Kamandaka character, besides the urge to highlight the regions to be different from the other variants. Major character group is a main character or characters that have an important role in the story of Raden Kamandaka, while the minor group is a supporting figure whose not too important role in story variants. Variant II, III, IV, VII, and $\mathrm{X}$ has the important events that are assumed to be the main variant. The main variants represent a community response to keep more complete Raden Kamandaka story. This variant is the one that can be considered as a master story.

Variant excluded to the main variant is regarded as supporting or complementary variant because it has no significant events that drives Raden Banyak Catra to perform the next action. The stories in the complementary variant represents the public memory of Raden Kamandaka characters in their region. People just remember that the territory as a transit area of Raden Banyak Catra. They are not so remember of action and events Raden Banyak Catra.

The variants from informant that generate main variant assumed to be the central regions of Raden Kamandaka story: variant II of the District of North Purwokerto, variant III of the District Karanglewas, variant IV of the District of North Purwokerto, Varian VII of the District of East Purwokerto, and Varian $\mathrm{X}$ of the District of South Purwokerto. Another variants considered as complement variant by showing movement of the story.

\section{REFERENCES}

Chatman, S. (1980). Story and Discourse Narrative Structure in Fiction and Film. Ithaca and London: Cornell Univarianty Press.

Danandjaja, J. (1984). Folklore Indonesia : Ilmu Gosip, Dongeng, dan lainlain. Jakarta: PT. Pustaka Utama Grafiti.

Hardjana, H.P. (1985). Raden Kamandaka. Jakarta: Balai Pustaka.

Hutomo, S.S. (1991). Mutiara yang Hilang : Pengantar Studi Sastra Lisan. Surabaya: HISKI Jawa Timur.

Nurgiyantoro, B. (2012). Teori Pengkajian Fiksi. Yogyakarta: Gadjah Mada Univarianty Press.

Priyadi, S. (1996). Teks Babad Pasir dalam Babad Banyumas Tradisi Naskah Dipayudan. Makalah Simposium Internasional Ilmu-Ilmu Humaniora III. Yogyakarta: Fakultas Sastra, Universitas Gadjah Mada.

Priyadi, S. (2002). Banyumas: Antara Jawa dan Sunda. Semarang: Penerbit Mimbar-The Ford Foundation-Yayasan Adikarya Ikapi.

Priyadi, S. (2002). Babad Pasir: Banyumas dan Sunda. Jurnal Humaniora. $14(2), 186-200$.
Rokhmansyah, A. (2016). Morfologi Cerita Rakyat Kutai Kartanegara Putri Silu: Analisis Naratologi Vladimir Propp. Seminar Antarbangsa. 263273.

Sabakti, S. (2016). Perbandingan Cerita "Mahligai Keloyang" dan "Koba Malin Deman". Jurnal Madah. 7(1), 97-114.

Setiawanti, Y. (2014). Rekonstruksi Cerita Rakyat Djaka Mruyung di Kabupaten Banyumas. Jurnal Sutasoma. 3(1), 42-48.

Taum, Y.Y. (2011). Studi Sastra Lisan: Sejarah, Teori, Metode dan Pendekatan Disertai Contoh Penerapannya. Yogyakarta: Lamalera. 